\title{
IMPLAN ZIRKONIA TIPE Y-TZP SEBAGAI PIRANTI ALTERNATIF PILIHAN SELAIN IMPLAN TITANIUM
}

\author{
(TYPE Y-TZP ZIRCONIA IMPLANT AS AN ALTERNATIVE CHOICE BESIDES \\ TITANIUM IMPLANT)
}

\author{
Dewi Puspitasari*, Ellyza Herda** \\ *Peserta Program Magister Ilmu Kedokteran Gigi Dasar \\ Fakultas Kedokteran Gigi, Universitas Indonesia \\ **Departemen Ilmu Material Kedokteran Gigi \\ Fakultas Kedokteran Gigi, Universitas Indonesia \\ Jl. Salemba Raya No.4 Jakarta Pusat 10430 \\ E-mail: dewident @gmail.com
}

\begin{abstract}
The used of implant in dental application has long evolved since titanium dental implants was firstly used, since then titanium became the material of choice. Due to the unwanted effects, zirconia as an alternative to titanium dental implant. The advantage of zirconia as a dental implant is biocompatibility and mechanical properties, the main mechanical properties of zirconia are the resistances to fracture through the mechanism of toughening transformation. Mechanism of toughening transformation occurred in zirconia which was stabilized by yttrium oxide, therefore the stress that is given to zirconia's surface will result in volumetric changing on crystal structure from tetragonal to monoclinic phase. In conclusion, zirconia mainly Y-TZP (tetragonal zirconia polycrystal) can be used as dental implant which is comparable to titanium dental implant.
\end{abstract}

Key words: zirconia, dental implant, toughening transformation

\begin{abstract}
Abstrak
Penggunaan implan dalam bidang kedokteran gigi telah berkembang sejak lama saat pertama kali implan berbahan dasar titanium digunakan untuk menggantikan gigi yang hilang. Sejak saat itu titanium menjadi material pilihan untuk penggunaan implan karena biokompatibilitas dan sifat mekaniknya yang baik. Adanya efek yang tidak diinginkan dari implan titanium, menjadikan material lain yaitu zirkonia sebagai material pilihan alternatif selain titanium. Keuntungan zirkonia sebagai implan antara lain biokompatibilitas dan sifat mekaniknya yang baik terutama resistensi terhadap fraktur melalui mekanisme "toughening transformation". Mekanisme "toughening transformation" terjadi pada zirkonia yang telah distabilisasi dengan oksida yttria (Y-TZP), sehingga stress yang terjadi pada permukaan zirkonia akan menghasilkan perubahan volumetrik pada struktur kristal dari fasa tetragonal menjadi fasa monoklinik. Sebagai kesimpulan, material keramik zirkonia terutama Y-TZP (tetragonal zirconia polycrystal) dapat digunakan sebagai material implan kedokteran gigi yang sebanding dengan implan titanium.
\end{abstract}

Kata kunci: zirkonia, implan gigi, toughening transformation.

\section{PENDAHULUAN}

Implan gigi atau dental implant merupakan piranti yang dapat menggantikan gigi yang hilang pada daerah edentulous dan mempunyai fungsi serta penampilan yang hampir sama dengan gigi asli. Penggunaan implan di bidang kedokteran gigi telah berkembang sejak 4 dekade yang lalu saat pertama kali implan berbahan dasar titanium diaplikasikan oleh Branemark. ${ }^{1}$ Sejak saat itu titanium menjadi material pilihan untuk penggunaan implan karena biokompatibilitasnya dan sifat mekanis yang baik. ${ }^{2}$ Akhirakhir ini hasil riset klinis melaporkan bahwa implan titanium dapat menyebabkan alergi dan tampilan estetisnya tidak memuaskan, hal ini mendorong para peneliti untuk mencari alternatif implan yang se- 
banding dengan titanium. Alternatif implan selain berbahan dasar titanium yang kini berkembang di kedokteran gigi adalah implan berbahan dasar zirkonia. Implan zirkonia bersifat biokompatibel, sewarna dengan gigi dan memiliki sifat mekanik yang baik. ${ }^{3,4}$ Sifat biokompatibilitas yang baik didapat dengan adanya osseointegrasi dengan jaringan sekitarnya. ${ }^{4}$

Material keramik zirkonia memiliki ketangguhan terhadap fraktur (fracture toughness) yang tinggi, ketangguhan ini dihasilkan dari stabilisasi fasa tetragonal dengan oksida yang berbeda yaitu Yttria dan disebut sebagai Yttria-stabilized tetragonal zirconia polycrystal (Y-TZP). Fenomena toughening transformation memberikan kontribusi untuk kekuatan dan ketangguhan yang tinggi dalam mencegah terjadinya retak pada material zirkonia. Peningkatan pada kekuatan dan ketangguhan merupakan alasan utama zirkonia digunakan sebagai implan gigi. ${ }^{5,6}$ Material ini menjadi pilihan untuk "generasi baru" implan gigi dibandingkan material keramik lainnya. ${ }^{7}$

Makalah ini merupakan telaah pustaka mengenai implan zirkonia sebagai alternatif pilihan untuk implan gigi yang sebanding dengan implan titanium, berdasarkan hasil penelitian yang telah dipublikasikan sebelumnya terutama dalam hal biokompatibiltas dan fracture toughness zirkonia yang tinggi melalui mekanisme "transformation toughening".

\section{IMPLAN ZIRKONIA}

Zirkonium adalah unsur logam yang memiliki simbol $\mathrm{Zr}$ dan nomor atom 40. Elemen ini merupakan elemen transisi dan memiliki berat atom 91,224. Zirkonium tidak terjadi di alam dalam keadaan murni tetapi bergabung dengan oksida silikat $\left(\mathrm{ZrO}_{2} \mathrm{X} \mathrm{SiO}{ }_{2}\right)$ atau oksida bebas $\left(\mathrm{ZrO}_{2}\right){ }^{8}$ Zirkonium dioksida atau Zirkonia $\left(\mathrm{ZrO}_{2}\right)$ dapat dibagi menjadi beberapa terminologi, salah satunya adalah Y-TZP (Yttria-stabilized tetragonal zirconia polycrystal). ${ }^{9}$ Keramik zirkonia tipe Y-TZP terdiri atas 100\% butir-butir halus tetragonal metastabil yang telah ditambah sekitar 2 sampai 3 mol \% Yttrium oksida $\left(\mathrm{Y}_{2} \mathrm{O}_{3}\right)$ sebagai bahan stabilisasi. Fasa-fasa yang terdapat dalam zirkonia adalah fasa tetragonal, monoklinik dan kubik. ${ }^{10}$ Fraksi fasa tetragonal dipertahankan pada temperatur kamar tergantung pada temperatur pemrosesan, kandungan yttrium dan ukuran butir. Berdasarkan ukuran butir, sifat mekanik zirkonia dapat ditingkatkan dengan mikrostruktur metastabil yang berukuran kecil. Fasa zirkonia tetragonal tetap dalam keadaan metastabil, hal ini berarti terdapat beberapa energi yang tertahan pada material zirkonia yang mampu kembali ke keadaan monoklinik jika struktur material diberikan stres. $^{11}$

Keramik zirkonia TIPE Y-TZP telah lama digunakan secara luas dalam bidang ortopedi sebagai hip-joint ball-heads. ${ }^{12,13}$ Dalam bidang kedokteran gigi, zirkonia tipe Y-TZP digunakan sebagai material untuk restorasi gigi tiruan tetap, untuk all ceramic abutments pada implan dan baru-baru ini sebagai implan gigi. ${ }^{4}$ Zirkonia tipe Y-TZP memberikan keuntungan yang lebih besar sebagai implan gigi dalam hal sifat fisik dan mekanis dibandingkan dengan material keramik lainnya. ${ }^{12}$ Dalam beberapa tahun terakhir material ini telah banyak digunakan sebagai implan oleh karena adanya efek stabilitas, estetis, sifat mekanis dan biokompatibilitas yang baik. ${ }^{10,14}$

\section{KELEBIHAN ZIRKONIA SEBAGAI IMPLAN DIBANDINGKAN DENGAN TITANIUM}

Implan gigi yang berbahan dasar titanium merupakan material implan yang pertama kali dan tetap digunakan hingga sekarang. Implan titanium memiliki performa klinis dengan tingkat keberhasilan kumulatif 98,8\% selama 15 tahun. ${ }^{1}$ Performa ini disebabkan oleh biokompatibilitas yang tinggi, respons tulang dan jaringan lunak yang menguntungkan terhadap implan serta kekuatan dan ketahanan korosi yang memadai. ${ }^{1,14}$ Peningkatan permintaan dan harapan pasien terhadap perawatan implan gigi semakin tinggi dan membuat dokter gigi tidak hanya tertarik pada osseointegrasi dan usia pemakaian klinis implan pada jangka panjang, tetapi juga memperhatikan hasil estetika perawatan. ${ }^{1}$

Hasil estetis restorasi yang didukung oleh implan titanium dapat terpengaruh jika warna gelap implan terlihat melalui peri-implan mukosa yang tipis atau jika terjadi resesi jaringan lunak sehingga bagian abutment implan terlihat. Selain itu, dinyatakan juga material ini berpengaruh terhadap kesehatan karena adanya partikel titanium yang lepas dan produk korosi. Adanya peningkatan konsentrasi titanium telah terdeteksi pada permukaan yang dekat dengan jaringan dan kelenjar getah bening di sekitar implan. Meskipun relevansi klinis dari temuan ini belum jelas, tetapi telah banyak peningkatan jumlah pasien yang lebih memilih perawatan yang bebas dari logam. ${ }^{4}$ Efek samping yang mungkin ada pada penggunaan bahan logam dan kecenderungan untuk membatasi penggunaan logam dalam tubuh manusia telah mendukung untuk mencari material yang lebih biokompatibel, salah satunya adalah material keramik zirkonia tipe Y-TZP. ${ }^{15}$ Sevilla dkk. menyatakan bahwa kelebihan (Y-TZP) dibandingkan implan titanium murni komersial atau Ti6Al4V adalah hasil estetis yang lebih baik karena warnanya putih meng- 
kilap yang ditunjukkan melalui mukosa tipis dan juga biokompatibilitas yang tinggi karena tidak ada ion logam yang keluar ke jaringan sekitarnya. ${ }^{15}$ Evard dkk. menyatakan bahwa ada peningkatan prevalensi alergi oral terhadap logam, termasuk emas dan titanium yang digunakan dalam kedokteran gigi terutama pada pasien dengan riwayat alergi terhadap logam. Implan titanium dapat memicu toksisitas atau reaksi alergi tipe I atau IV dan juga adanya kekhawatiran tentang penglepasan ion titanium karena korosi, keausan, alergi dan sensitisasi. Konsentrasi tinggi ion titanium terdeteksi secara lokal dan sistemik, secara lokal yaitu pada tulang di sekitar implan dan secara sistemik dalam kelenjar getah bening regional, organ internal serta mencapai serum dan urine yang berpotensi berbahaya bagi tubuh manusia. Kekhawatiran terus berkembang terkait dengan paduan logam dan adanya laporan yang menghubungkan penyakit sistemik dan mutasi genetik dengan adanya penglepasan ion logam dari restorasi. ${ }^{1}$

Sevilla dkk. dalam penelitiannya menyatakan bahwa implan zirkonia Y-TZP memiliki resistensi yang lebih tinggi terhadap fraktur bila dibandingkan implan titanium apabila kemiringan penanaman implan zirkonia Y-TZP kurang dari $20^{\circ}$ terhadap sumbu gaya pengunyahan. Sudut inklinasi yang lebih besar dari $20^{\circ}$ menunjukkan lebih mudah terjadi fraktur bila dibandingkan dengan implan titanium. ${ }^{15}$ Butz dkk. juga menyatakan bahwa abutment implan dari bahan dasar zirkonia memiliki kekuatan yang sebanding dengan implan titanium untuk melawan fraktur akibat simulasi gaya pengunyahan yang diberikan, dengan demikian implan zirkonia sangat baik bila digunakan untuk implan gigi anterior maupun posterior (Gambar 1 dan 2). ${ }^{1,16,17}$

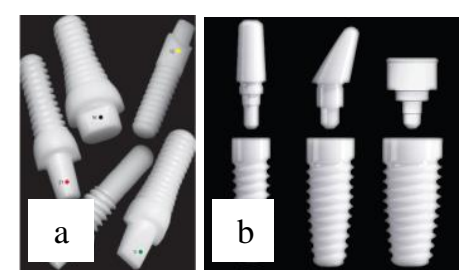

Gambar 1. (a) Implan zirkonia one piece dengan indikasi yang berbeda (insisivus, kaninus, premolar dan molar); (b) implan zirkonia two piece $e^{17}$

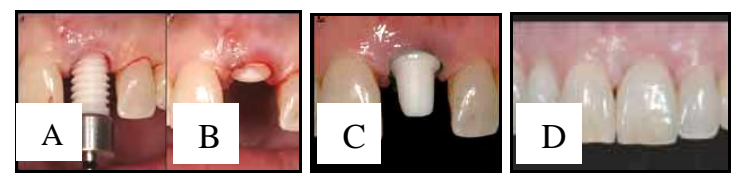

Gambar 2. Aplikasi implan zirkonia (A, B, C) dan sementasi mahkota pada gigi insisivus pertama atas kiri (D) ${ }^{1}$

\section{SIFAT MEKANIS ZIRKONIA}

Zirkonium dioksida $(\mathrm{ZrO} 2)$ atau disebut Zirkonia merupakan oksida logam bioinert nonresorbable dengan sifat mekanis yang lebih baik dibandingkan dengan biomaterial keramik lainnya. ${ }^{13}$ Zirkonia merupakan material polimorfis yang memiliki struktur kristal yang berbeda yaitu monoklinik (M), kubik (C) dan tetragonal (T). Pada temperatur kamar zirkonia murni berada pada fasa monoklinik. Fasa ini stabil sampai temperatur $1.170^{\circ} \mathrm{C}$. Peningkatan temperatur sampai $2.370^{\circ} \mathrm{C}$ zirkonia mengalami fasa tetragonal kemudian diatas $2.370^{\circ} \mathrm{C}$ zirkonia berada pada fasa kubik. Struktur zirkonia yang dapat bertransformasi menjadi monoklinik, kubik dan teragonal disebut sebagai struktur metastabil. ${ }^{18}$ Pada Gambar 3 ditunjukkan diagram transformasi fasa struktur kristal zirkonia. ${ }^{8,18}$

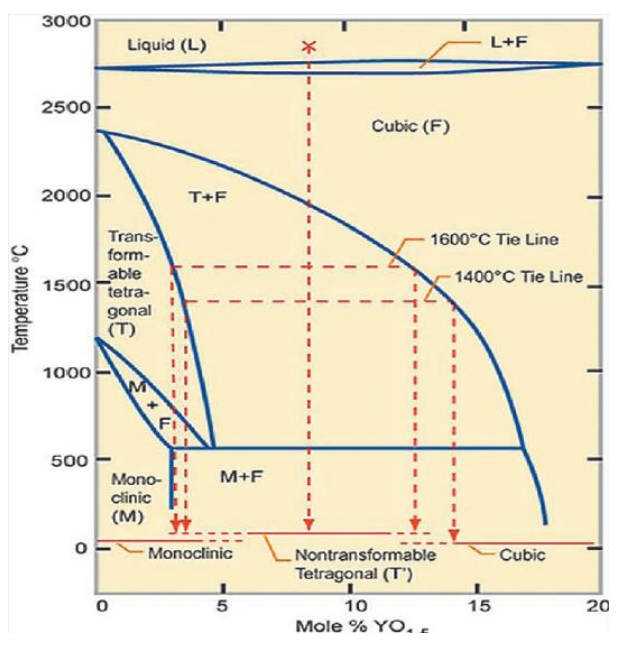

Gambar 3. Diagram Fasa Y-TZP ${ }^{8}$

Sifat mekanis zirkonia tipe Y-TZP dapat dikaitkan dengan struktur butirnya yang halus dan mempunyai mikrostruktur metastabil. Sifat mekanis yang tinggi merupakan hasil mekanisme transformation toughening, mekanisme ini merupakan transformasi material antara fasa yang berbeda dan bertindak sebagai proses penguatan untuk melawan retakan yang dapat menyebabkan kegagalan material. ${ }^{11} \mathrm{Si}$ fat mekanis yang tinggi ditunjukkan melalui fracture toughness yang tinggi yaitu 7 hingga $10 \mathrm{MPam}^{-}$ 1 , ketangguhan yang tinggi ini merupakan kemampuan material untuk melawan penjalaran retak karena beban pengunyahan yang besar. Zirkonia tipe Y-TZP juga menunjukkan kekuatan fleksural yang tinggi antara 900-1200 MPa, modulus Young sebesar 210 GPa yang menunjukkan kekakuan yang sebanding dengan stainless steel, kekuatan kompresif sebesar $4900 \mathrm{MPa}$ dan kekuatan impak 137 $\mathrm{MPa}^{8,13,16}$ 


\section{PEMBAHASAN}

Zirkonia memiliki tiga perubahan fasa pada temperatur tertentu. Pada proses sintering zirkonia mengalami transformasi kristal dari fasa monoklinik ke tetragonal dan akan mengalami transformasi ke fasa monoklinik kembali bila ada stres sehingga menyebabkan adanya mekanisme penguatan yang disebut transformation toughening. ${ }^{19}$ Pada temperatur kamar zirkonia murni berada pada fasa monoklinik. Fasa ini stabil sampai temperatur $1.170^{\circ} \mathrm{C}$. Pada peningkatan temperatur sampai $2.370^{\circ} \mathrm{C}$ zirkonia mengalami fasa tetragonal dan temperatur diatas $2.370^{\circ} \mathrm{C}$ zirkonia berada pada fasa kubik. Sebaliknya, selama penurunan temperatur, transformasi dari fasa tetragonal ke fasa monoklinik terjadi pada temperatur dibawah $1.070^{\circ} \mathrm{C}$ dan diikuti dengan terjadinya ekspansi volume sekitar 3-4\%. Transformasi fasa ini akan menyebabkan stres yang berlanjut pada pembentukan retakan. Untuk mencegah pembentukkan keretakan tersebut maka zirkonia perlu dilakukan stabilisasi. . $^{819}$

Dengan penambahan sejumlah kecil oksida penstabil (yttria), partikel tetragonal bisa tetap bertahan dalam bentuk metastabil pada temperatur dibawah temperatur transformasi fasa tetragonal ke fasa monoklinik. Stabilitas ini disebabkan oleh karena energi permukaan pada fasa tetragonal lebih rendah dibandingkan fasa monoklinik dan juga karena fasa tetragonal melawan untuk bertransformasi ke bentuk monoklinik. ${ }^{8}$

Penjalaran retak menyebabkan terjadinya stres terhadap butir-butir sekitar retak sehingga butir tetragonal dapat bertransformasi menjadi monoklinik dan mengalami ekspansi volume sekitar 3-5\%. Ekspansi ini akan menyebabkan stres kompresif terhadap bagian ujung awal retak, sehingga dapat menahan penjalaran retak lebih besar. Energi yang lebih besar dibutuhkan untuk meyebabkan terjadinya penjalaran retak lebih lanjut, sehingga cara ini bekerja dengan baik untuk mencegah terjadinya penjalaran retak. Transformasi ketangguhan keramik zirkonia berasal dari pembentukan lapisan kompresif yang terjadi di permukaan. ${ }^{8,15,16}$ Setiap transisi antara struktur kristal dari tetragonal ke monoklinik yang disebabkan oleh karena stres yang diberikan pada permukaan zirkonia akan menghasilkan perubahan volumetrik pada struktur kristal tersebut. Energi retak akan menciptakan transisi tetragonal ke monoklinik, modifikasi struktur kristalin ini akan diikuti oleh ekspansi yang menutup retak. ${ }^{16}$ Energi yang seharusnya digunakan untuk perambatan retak habis untuk mengatasi stres kompresif yang disebabkan oleh ekspansi volume pada transformasi fasa tetragonal ke monoklinik. ${ }^{15}$
Transformasi fasa ini menempatkan retakan pada tekanan oleh karena ukuran butir yang membesar sehingga akan memperlambat pertumbuhan retak. Dengan adanya transformasi ini akan diperoleh peningkatan dalam ketangguhan karena energi yang digunakan untuk perambatan retak dihilangkan dengan baik oleh transformasi fasa tetragonal ke monoklinik. Mekanisme ini dikenal sebagai transformation toughening dan dianggap menjadi dasar bagi kekuatan dan fracture toughness yang tinggi pada zirkonia yttria-tetragonal zirconia polycrystal $(\mathrm{Y}-\mathrm{TZP}){ }^{9,10}$

Sebagai kesimpulan, material keramik zirkonia tipe Y-TZP (tetragonal zirconia polycrystal) digunakan sebagai material pilihan untuk implan kedokteran gigi selain implan titanium karena biokompatibilitasnya dan sifat mekanik yang baik. Sifat mekanik Y-TZP yang tinggi terutama diperoleh dari ketangguhan terhadap fraktur (fracture toughness) yang tinggi melalui mekanisme transformation toughening.

\section{Daftar Pustaka}

1. Jum'ah AA, Beekmans BMN, Wood DJ, Maghaireh H. Zirconia implants: The new arrival in the armoury of successful aesthetic implant dentistry. Smile Dent J 2012; 7(2): 12-26.

2. Depprich R, Zipprich H, Ommerborn M, Naujoks C, Wiesmann H-P, Kiattavorncharoen $\mathrm{S}$, et al. Osseointegration of zirconia implants compared with titanium: an in vivo study. Head \& Face Medicine 2008; 4(30): 1-8.

3. Özkurt Z, Kazazoğlu E. Zirconia dental implants: a literature review. J Oral Implantol 2011; 37(3): 367-76.

4. Wenz HJ, Bartsch J, Wolfart S, Kern M. Osseointegration and clinical success of zirconia dental implants: a systematic review. Int J Prosthodont 2008; 21(1): 27-36.

5. Denry I, Holloway JA. Ceramics for dental applications: a review. Materials 2010; 3(1): 351-68.

6. Triwatana P, Nagaviroj N, Tulapornchai C. Clinical performance and failures of zirconia-based fixed partial dentures: a review literature. $\mathrm{J} \mathrm{Adv}$ Prosthodont 2012; 4(2): 76-83.

7. Hisbergues $\mathrm{M}$, Vendeville $\mathrm{S}$, Vendeville $\mathrm{P}$. Zirconia: established facts and perspectives for a biomaterial in dental implantology. J Biomed Mater Res B Appl Biomater 2009; 88(2): 519-29.

8. Vagkopoulou T, Koutayas SO, Koidis P, Srub JR. Zirconia in dentistry : Part 1. Discovering the nature of an upcoming bioceramic. Eur J Esthet Dent 2009; 4(2): 1-22.

9. Kelly JR, Denry I. Stabilized zirconia as a structural ceramic: An overview. Dent Mater 2008;24:289-98.

10. Amat NF, Muchtar A, Yahaya N, Ghazali MJ. A review of zirconia as a dental restorative 
material. Aust. J. Basic \& Appl. Sci 2012; 6(12): 9-13.

11. Andreiotelli M, Kohal R-J. Fracture strength of zirconia implants after artificial aging. Clin Implant Dent Relat Res 2009; 11(2): 158-66.

12. Depprich R, Zipprich H, Ommerborn M, Mahn E, Lammers L, Handschel J, et al. Osseointegration of zirconia implants: an SEM observation of the boneimplant interface. Head \& Face Medicine 2008; 4(25): 1-7.

13. Rieger W, Köbel S, Weber W. Processing and properties of zirconia ceramics for dental applications. Spectrum dialogue 2008: 1-12.

14. Shrestha S, Joshi S. Current concepts in biomaterials in dental implant. Sci Res 2014; 2(1): 7-12.

15. Sevilla P, Sandino C, Arciniegas M, MartínezGomis J, Peraire M, Gil FJ. Evaluating mechanical properties and degradation of YTZP dental implants. Mater Sci \& Eng : C 2010; 30(1): 14-19.

16. Manicone PF, Iommetti PR, Raffaelli L. An overview of Zirconia Ceramics: Basic Properties and Clinical Applications. J dent 2007; 35: 819-26.

17. Hochscheidt CJ, Alves EDM, Bernardes LAB, Hochscheidt ML, Hochscheidt RC. Zirconia dental implants: An alternative for today or for the future? (Part II). Dent Press Implantol 2012; 6(4): 114-24.

18. Nakamura K, Kanno T, Milleding P, Örtengren U. Zirconia as a dental implant abutment material: a systematic review. Int J Prosthodont 2010; 23(4): 299-309.

19. Hartono SB. Pengaruh presureless sintering terhadap fracture toughness komposit kaolinzirkonia. Traksi 2012; 12(2): 16-27. 